\title{
The First Contacts between China and Poland in History
}

\section{The First Contacts between China and Poland in History}

\section{Abstract}

Poland is one of the first countries to establish diplomatic relations with People's Republic of China. Since the establishment of diplomatic ties 70 years ago, both countries have conducted close cooperation in all areas and the bilateral relations have witnessed steady development. In particular, the "One Belt, One Road" initiative, launched in 2013, got the positive responses and support from many countries, including Poland, which became an important partner for China to promote the construction of the initiative. This paper, from a historical perspective, reviews the first interaction between China and Poland in the period of Yuan Dynasty which is arranged in chronological order. The narrations mainly concentrate on accounts of the western expeditions by Genghis Khan and his descendants as well as the Battle of Legnica, during the period of which the Mongolia Empire was successively set up. Each entry will include a concrete description, highlighting where possible issues such as where the Mongolia went, why the expedition and its record are important. The paper also expounds the first record about Poland and the change of the name of Poland in Chinese literature so as to deepen the mutual understanding between two countries.

Keywords: western expeditions, Genghis Khan, Battle of Legnica, Bolonia 


\section{Первые в истории контакты Китая и Польши}

\section{Аннотация}

Польша - одна из первых стран, установивших дипломатические отношения с Новым Китаем. С момента установления дипломатических отношений 70 лет назад обе страны поддерживают тесное сотрудничество во всех областях и двусторонние отношения стабильно развиваются. В частности, инициатива «Один пояс, один путь», запущенная в 2013 году, получила положительные отклики и поддержку многих стран, включая Польшу, которая стала для Китая важным партнером в продвижении инициативы строительства. В этой статье с исторической точки зрения рассматривается первое взаимодействие Китая и Польши в период династии Юань, что представлено в хронологическом порядке. Повествование в основном сосредоточено на рассказах о западных экспедициях Чингисхана и его потомков, а также о битве при Легнице, в период которой последовательно создавалась Монгольская империя. Статья также рассказывает о первом упоминании о Польше и изменении названия Польши в китайской литературе.

Ключевье слова: западные экспедиции, Чингисхан, Битва при Легнице, Болония

\section{Introduction}

The world of the $13^{\text {th }}$ century was divided into three great civilization 1 circles (Tatarkiewicz, 1978, p. 74-79). The politically diverse Europe treated itself as a whole and went by the name of the "Christian world". The Central Asia and Northern Africa were in control of Muslims. In the Far East, Chinese civilization, the most developed at the time, was spreading out widely to the surrounding areas - the Great Steppe to the North and Japan to the South (Gumilow, 1973, p. 76-80). The range of the Christian and Muslim civilizations was related to the religious offensive; the Chinese civilization was separated from them by large maritime distance and extensive spaces of the Great Steppe. The famous Great Wall of China not only laid along the geographic and ethnographic border, it was also a major obstacle, separating one of the oldest civilizations in the world from the North (Luo, Zhao, 1986, p. 7-9). The insulation of that border proved that, in cultural terms, the inhabitants of the Great Steppe was treated as "barbarians", and in political terms-enemies. However, this civilization impacted large areas of Asia, which during that period already reached European territory, especially 
the Southern and Eastern Mediterranean regions (Bartold, 1911, p. 25-29), in sort of spontaneous way.

The $13^{\text {th }}$ century bore the hallmarks of the new epoch. The Golden Byzantium begun to decline, while raised banners of the Crusaders were headed in the direction of the terrible confrontation with Muslims. It was a war of attrition between two great civilization circles, a war of the mystical religious nature, which also valuated the political and economic aspect. Soon after that, there appeared the Mongols near those circles.

The astonishing fact is that a small nation within 50 years conquered half of the world, however the mechanisms of that action wasn't completely clear, despite carefully reviewing the information provided by the sources, with the rigorous application of the historical critique (Pomorski, 1984, p. 31-55). According to the famous Far East researcher Lew Gumilow, the breakthrough in the economy of Great Steppe nations came when the wolves were exterminated with the help of domesticated dogs and trained eagles (Włodarski, 1992, p. 20; Gumilow, 1973, p. 29). Therefore, huge herds of horses and sheep started to multiply more intensively, which were basis of the nomad livestock on the Eurasian Steppe. It should be assumed here, that the horses with their numerous breeds revolutionized the Great Steppe, which brought this nation closer to the world. The real warrior was born and died on the horse (Łabęcka-Koecherowa, 1987, p. 55-66). Without the horses and the particular mentality of nomads, the creation and the expansion of the biggest imperial in recorded history would not have been possible. That were the nomads, who thanks to the mobility, were becoming the connectors among different, remote and isolated civilizational centres, and facilitated the consolidation of the conquered territories.

\section{The first expedition to the West by the Mongols}

In 12th century's Europe, there was a lack of any interest in Far East, even though gaining the information was relatively easily. The caravans were making regular trips from China to Baghdad and from there to Constantinople. Muslim traders were reaching Siberia, and the Nestorians had the trade between Central Asia and China at their disposal. The information exchange was possible. However, the Western Europe, claiming to be "the 


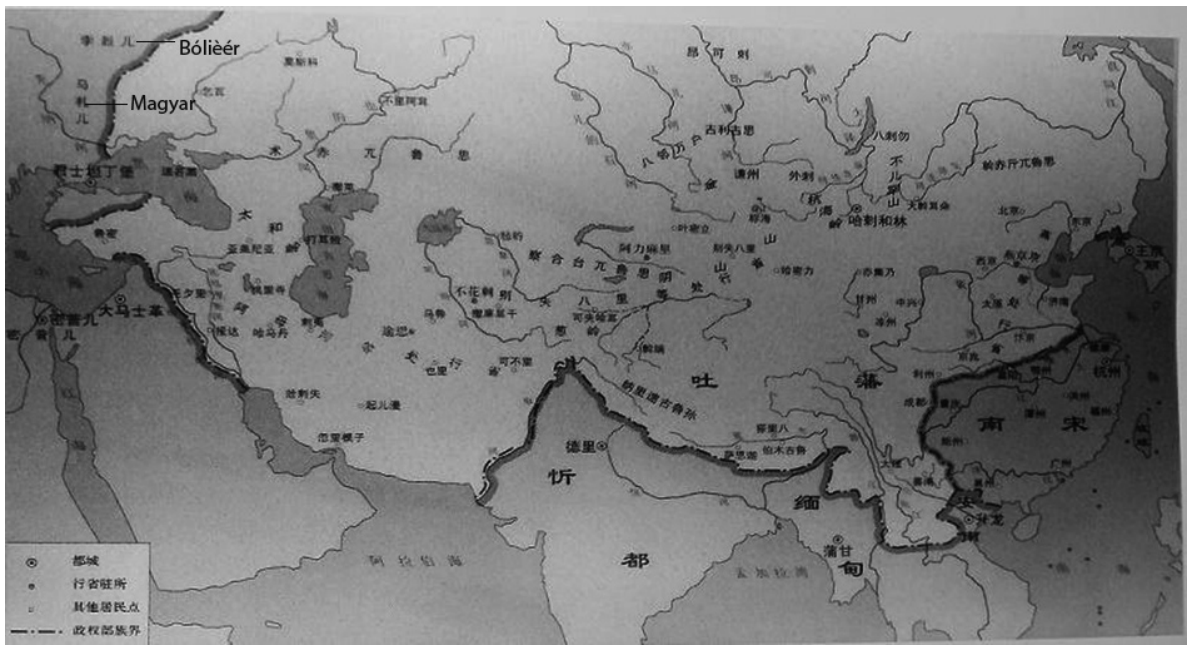

Map 1. The state of Mongol Khan ${ }^{1}$

Source: Capital Museum in Beijing (photo taken on July 5, 2017).

Christian world", excluded schismatics from Greeks and Ruthenia ${ }^{2}$. This did not prevent Muslim countries from forming a religious and cultural unity against Europe (i.e. the Franks and Byzantium) and disbelievers, including the Eurasian nomads.

The nomadic Mongolian tribes arose in northern China in the $12^{\text {th }}$ century, which had undergone tremendous changes in the course of world history. Hence, the fundamental question arises - how did it happen, that the tribes recognized by contemporaries as nomadic, being at low level in

${ }^{1}$ Ögedei Khan (1186-1241) set Shangshu province in Yanjing and collected together the world wealth there. During the reign of Möngke Khan (posthumous title: Xianzong, 1209-1259), Kublai, the brother of the emperor, managed all military affairs in the area of South Deseart. Yanjing with the unprecedented political and military status became the important stronghold where the North China and the Central Plains were controlled by Mongolia (1206-1271). It should be noted that the name of Poland - 孛烈儿 (pinyin: Bólieér) and name of Hungary - 马扎儿 (pinyin: Mǎzhāér, English language: Magyar) appear on upper left corner of the map.

2 The Pope Innocent III requested Poland, the Order, Sweden and Norway to no longer supply Ruthenia with iron. Aleksander Newski, after heavy fights with the Crusades on the Neva River (1240) and the Lake Peipus (1242), established a covenant with Batu-Khan's son, Sartak, and received aid from the Mongolian army. 
terms of civilization, and "living by plundering", took their own military art to a such a high level?

In 1206, Temujin (1162-1227), a noble of Borjigin clan, unified Mongolia and was elected as Khan with the honorable title "Genghis Khan", which means "God-given Khan" (Shen, 2014, p. 202). Then he started a series of reforms of the Mongol army which strengthened the army extremely. The ancestral laws were broken consciously, and the commanders received awards according to the war contributions. The military regulations were adopted as the basis for legislation, which was helpful for the control by the governors. In addition, it was the fierce battles with Chinese which allowed to remain the Mongolian independence and create a culture adapted to their form of life. Due to mastering the technique of fighting on horseback and ability to changing encampment, the Mongols avoided the assimilation among Chinese people. Moreover, the reception of Chinese military art was characteristic of the Mongols, especially after the conquest of the northern state of Jin (Luo, Zhao, 1986, p. 9). Instead of remaining passive observers or just copycats of Chinese military art, the Mongols adjusted to their needs and enriched elements gained from the battles with neighbouring states.

In 1218, Genghis Khan, in accordance with the trade agreement between Mongolia and Khwarezm, sent a large trade mission consisting of 450 people with Khan's letter to the Shah and the precious commodities such as gold, silver, silk, marten fur, etc. to the state. However, at the town of Otrar the governor, believing a greedy guard's slanderous talk to suspect the Khan's ambassadors to be spies, confiscated the goods and executed them. Unfortunately, the Shah refused to pay the reparations demanded by Genghis Khan. In 1219, the first Mongolian exploratory expedition to the West was taken with the attack of Khwarezm for the purpose of revenge (Grousset, 2004, p. 302). In order to make an end of Sultan, Genghis Khan dispatched two best commanders Jebe (1181-1223) and Sübetei (1175-1248) and chose proportionately thirty thousand men from the troops (Ata-Malik, 1958, p. 169).

After crushing Georgians, Armenians, Azerbaijanis, the nomadic Kipchak tribes, Alans and Lezgins, Jebe and Sübetei faced off in a bloody battle with the troops of Russian princes and their Cuman (one of Kipchak tribes) supporters on the Kalka River in May 31, 1223 (Grousset, 2004, p. 308-315). The battle ending in the huge failure of "allied" Russian troops and Cumans 
received widespread coverage in whole Ruthenia, and even reached China. Probably the news about the battle reached Polish territory as well, whereas the Mongols seemed to be very distant. It was hard to believe in reliability of threat from people located so far away, calculated as months or years of travelling on horses. Genghis Khan's order to "turn horses' mouths back" caused that Mongolians disappeared as quickly as they appeared. Apparently, the primary objective of avenging the dead ambassadors was accomplished by the expedition, meanwhile Mongolians acquired new living space as well as gathered valuable loot. This exploratory trip also set the foundation for future Mongolian “Great Journey” to Europe.

In 1224 Genghis Khan received the first European at his court, who reached Central Asia "wandering" through the marshes over the upper Irtysh. The Englishman Anonim, a participant in the Crusade, went from the Middle East through Asia Minor and Caucasus to Crimea in direction of Central Asia, where he met Genghis Khan. The Englishman drew the attention of the Great Khan to the rich Western Europe, contrasting with poor court of "Lord of half the world". Long talks with Englishman probably confirmed previous information provided by Venetian merchants, who were regular medium of news about economy and political relationships as well as climate and topography of the European countries. With the trust of the Great Khan, Anonim visited the capital, developed with a huge and verve Karakorum located in North Mongolia on the Orkhon River. After a longer stay, he easily returned to Europe through Kiev and reached Venice (Jackson, 2007, p. 98-99).

\section{The second expedition to the West}

After the death of Genghis Khan, the expedition to Europe had already been discussed in Kurultai during the election of Great Khan Ögedei (1229-1241) in the autumn of 1229. The decision about second expedition to the West was probably made in 1235 in the Mongolian capital, Karakorum. Ögedei appointed Batu, the first Khan from the Golden Horde, to the position of commander who had the best insight into European relations. However, the command of the actual operation for the troops comprised of 50,000-60,000 warriors from the Mongol Empire was assigned to the second son of Jochi, 
Sübetei, who didn't fail even once (Bai, Zhao, 1982, p. 316; Gumilow, 1973, p. 159). They were accompanied by numerous princes: Batu Khan's brothers Berke, Orda and Shayban, Tolui's son Möngke, Chagatai's son Baidar and descendants of Ögedei, Güjük and Kadan, which is the reason the Mongol invasion of Europe is referred to as "Princes' Expedition to the West" by many Chinese scholars. The predominant group in the military technical services was Chinese soldiers operating catapults, battle flames, gunpowder and smoke grenade launcher, etc. (Luo, Zhao, 1986, p. 63-65). In 1237 Volga Bulgaria was controlled, and the territory of Mordvins and Burtas were seized by force. The remaining part of Kipchak steppes populated by Cumans and Alans were conquered. Meanwhile, the Cheremis and the Votyaks (also known as Udmurts) were also subordinated (Grousset, 2004, p. 313-315). The way to Ruthenian principalities and states of Central and Eastern Europe was opened for the second expedition to the West.

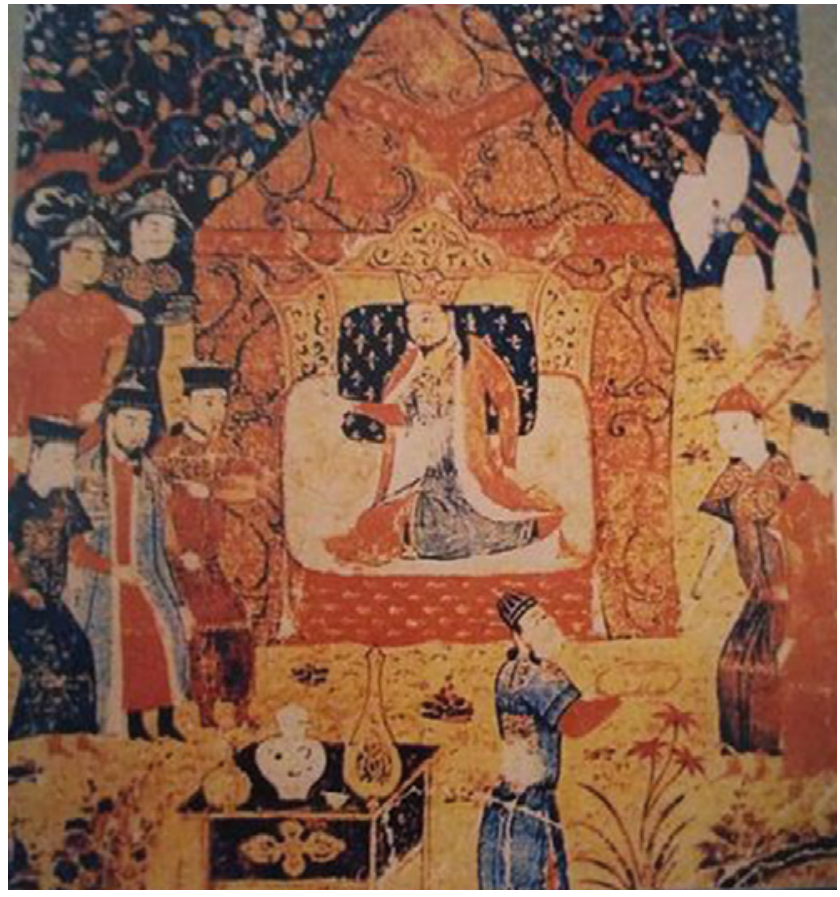

Image 1. Meeting with the Mongol $\mathrm{Khan}^{3}$

Source: Capital Museum in Beijing (photo taken on July 5, 2017).

3 The image records the scene that the envoys of all countries have been presented to Ögedei Khan after his election. 
During the years 1239-1240, the Mongols, with the full of surprise effect, invaded South Ruthenia and conquered Kiev and Chernihiv. Kiev was hit particularly hard, where the local residents murdered Mongolian parliamentarians. In the beginning of 1241, the two Mongolian armies under the leadership of Batu and Sübetei cracked down on Hungary, while the third under Orda, Baidar and Kadan assaulted Poland, which was treated as the first step to conquer Central Europe.

Baidar and Kadan ravaged the southern part of Poland: they sacked Sandomierz first, then defeated the organised but inefficient resistance of Polish armies in Tursko and at Chmielnik respectively. One of the Mongolian army troops led by Baidar moved from there to Krakow where was seized and burned down, and to Opole. The second troop led by Kadan made a circle and reached Leczyca and Sieradz. Both troops joined together in Silesia (Hildinger, 1997).

In the study of Genghis Khan written by Rene Grousset and translated into Chinese by Tan Fayü, there is a reproduction showing the effects of the Mongol invasion of the Kingdom of Hungary during the second western expedition in the years 1240-1241. The engraving was titled with "The

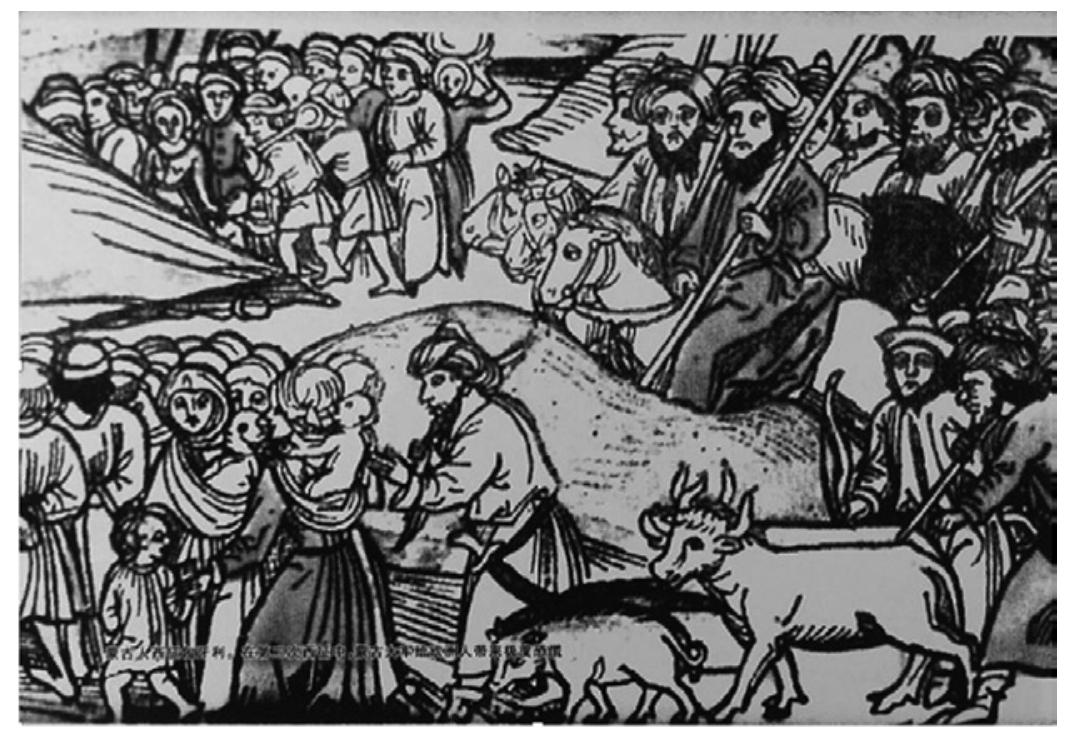

Image 2. The Mongols invaded Hungary

Source: Grousset, 2004, p. 320. 
Mongols invaded Hungary. In the second expedition to the West they brought Europeans extreme panic" (Grousset, 2004, p. 320; see Image No. 2). It depicts the Mongols wearing typical pointed hats which were called, in European sources, "pagan headgear" and "Muslim turban". The invaders arming with long spears captured people and robbed cattle in haste. It should be stated that the image, without Mongolian or Chinese provenance, was probably created in the European cultural circle. It is regrettable that the author did not cite the source of the illustration, nor the Chinese publisher.

\section{The Battle of Legnica}

The contact of Poles with products of Chinese civilization was not always necessarily pleasant or only indifferent as well as profitable. The Mongolian invasion of Poland in 1241 with its culmination - the Battle of Legnica, which caused the death of Duke Henry II the Pious and led to the great disaster.

The biggest armed confrontation of Henry II's forces (including the Bavarian miners, the knights of Greater Poland, the army of Opole, Teutonic Knights from Prussia and small reinforcements of Templars) with Mongols and Far East's military tactics took place on April 9, 1241 near Legnica at Legnickie Pole (Polish for "Field of Legnica"), also known as Wahlstatt (Chambers, 1979). A diametrical difference in the understanding of struggle strategy between Henry II's knights and Orda's army proved the undisputed superiority of Mongolian tactics. The Silesians and knight troops were surprised by the maneuver that the mock retreat from the front was used by the Mongolian troops to extend the detachment line of Henry II's troops and to strike on the exposed right wing of the Silesian army. Besides, the Russian knights were employed to serve for the Mongolian army in order to make the "escape" seem more real.

The Mongols used stirrups to enforce better control of the horses, and recurve bows to launch arrows in a much faster and more efficient way (Sikorski, 1975, p. 210). When the massive attack of heavy-armed rides did not bring any desired results, the Mongols used the weapons that were far ahead of the era, such as suffocating gases, smokescreens, kites with firecrackers, etc. (Maron', 2011, p. 18-20). Due to the fact that these weapons were still new ones, even for Mongols, and there were also Chinese people 
who had joined the western expedition (in the technical services), it should be noted, that devices ejecting gas and smoke, with other additions, from the burnt gunpowder were operated by Chinese in the Battle of Legnica. The Polish chronicle writer Jan Dlugosz describes the fragment of this battle in the following way:

[...] there was in their (Mongolian) army one huge size... at the top of its shaft was a very ugly and monstrous head with a beard, so when the Tatars withdrew some hundred paces and took away, the lieut carrying the pennant started waving the huge head with all his strength, from which there immediately burst out a dense steam with smoke and a foul and deadly smell that enveloped the Poles and made them all but faint, even if barely alive would have no strength and stop (that is, they fell) fighting [...] (Długosz, 1975, p. 11; Włodarski, Zhao, 2014, p. 17).

Why does the Polish chronicle writer not indicate the presence of Chinese people? Probably, Polish knights generously fighting with people which were so alien for them could not recognize Chinese among Mongols. Furthermore, the confusion of Polish troops was increased by smokescreens, which facilitated the encirclement by Mongolian army and a direct attack by Mongolian cavalries. The Polish knights not only suffocated from fumes of sulfur but also felt some fear of the unknown. They rushed to escape so that they had no time to distinguish enemies nor think about something else.

For the first time, Polish knights met with Chinese inventions on such a scale. Apparently, none of the participants in this battle did not realize that the Mongols, consciously or not, familiarized the inhabitants of Central and Eastern Europe with Chinese inventions. Therefore, the first contact of Chinese people with Poland should be regarded to be made in the year of 1241 (Włodarski, Zhao, 2014, p. 17).

A similar inconsistency and even error concerning the image without any title was published in the work of R. Grousset and noted: "Jebe and Sübetei accepted his (Ögedei) order to continue the conquest of the West. They managed to defeat the Persians of the Caucasian Turks and Russians for opening the door to the second Mongol expedition to Europe" (Grousset, 2004, p. 319). The fact is that this image is a fragment of the Western chronicle 


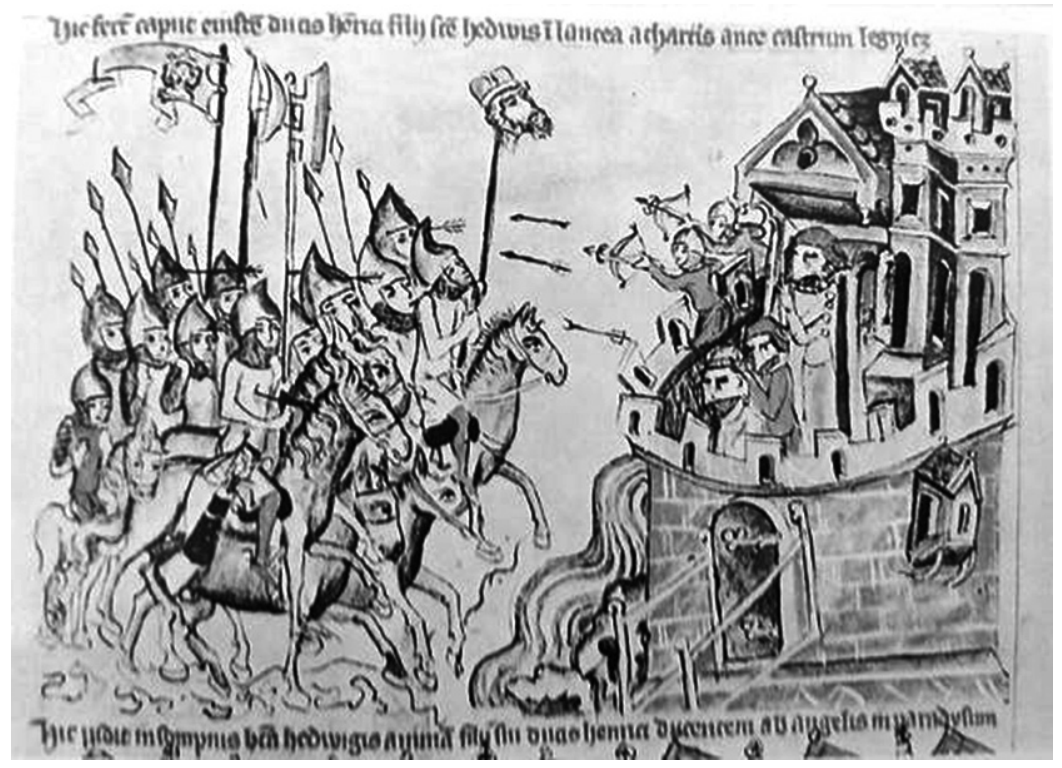

Image 3. The Battle of Legnica

Source: Grousset, 2004, p. 319.

and presents the siege of the city of Legnica in Poland after April 9, 1241. A Mongol cavalry on the horse carries a long spear on the top of which the head of the Silesian prince Henry II the Pious is hung who was killed in the battle near Legnica.

\section{The first record about Poland in Chinese literature}

One of the oldest oriental monuments The Secret History of Mongols highlighting military expeditions of the first two Genghisid (Genghis Khan and his son Ögedei) takes into account the warfare in "Western lands" in years 1236-1240. The original of this well-known literature was written in old Uyghur alphabet, the language of the ancient Mongols. The initial Mongol-Uyghur version of this monument was lost quite early, while the Chinese transcription of the Mongol text "with interlinear translation of the particular words and shortened as well as fairly free Chinese translation" had survived (Kałużyński, 1970, p. 10). Commissioned by the Chinese court, the 
text with the title Yuan Shi [The History of Yuan] which was composed by the official Bureau of History of the Ming Dynasty, under direction of Song Lian (1310-1381), became part of the official yearbook of Chinese imperial family history with Mongol roots. This historical work chronicles the history from the time of Genghis Khan to the flight of the last Yuan emperor, Toghon Temür (Emperor Huizong, 1333-1370), in which Biographies as one of four main parts details important non-imperial people of the era. The Chinese entry 孛烈儿 (pinyin: Bólièér) which means Poland was recorded in the notable biography of an Uriankhai general Sübetei (volume 121; Song Lian). It also occurs in many Chinese documentations (see Map No. 1 and No. 3). We will come back to the origin of this entry in further deliberations.

By reviewing Arabian sources, especially The Compendium of Chronicles, written by Rashid-al-Din Hamadani (1247-1318), which is considered the first world history, the outstanding Polish historian and Arabist Jerzy Hauziński drew attention to the excerpt derived from Chinese history about Mongolian operations in Central and Eastern Europe, including Poland (Hauziński, 1997, p. 372-379). The text we are interested in reads as follows:

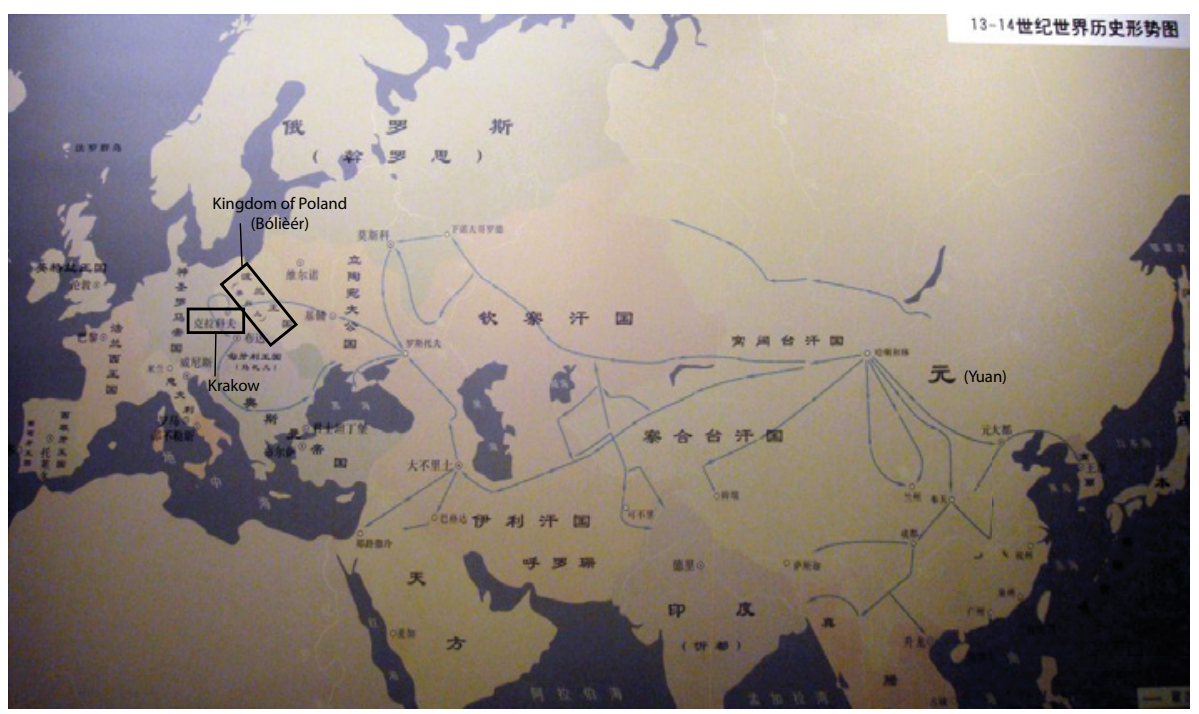

Map 2. World map of historical situation from the $13^{\text {th }}-14^{\text {th }}$ century ${ }^{\star}$

* The blue arrow lines indicate the routes of expeditions by Mongols.

Source: Capital Museum in Beijing (the photo was taken on July 5, 2017). 


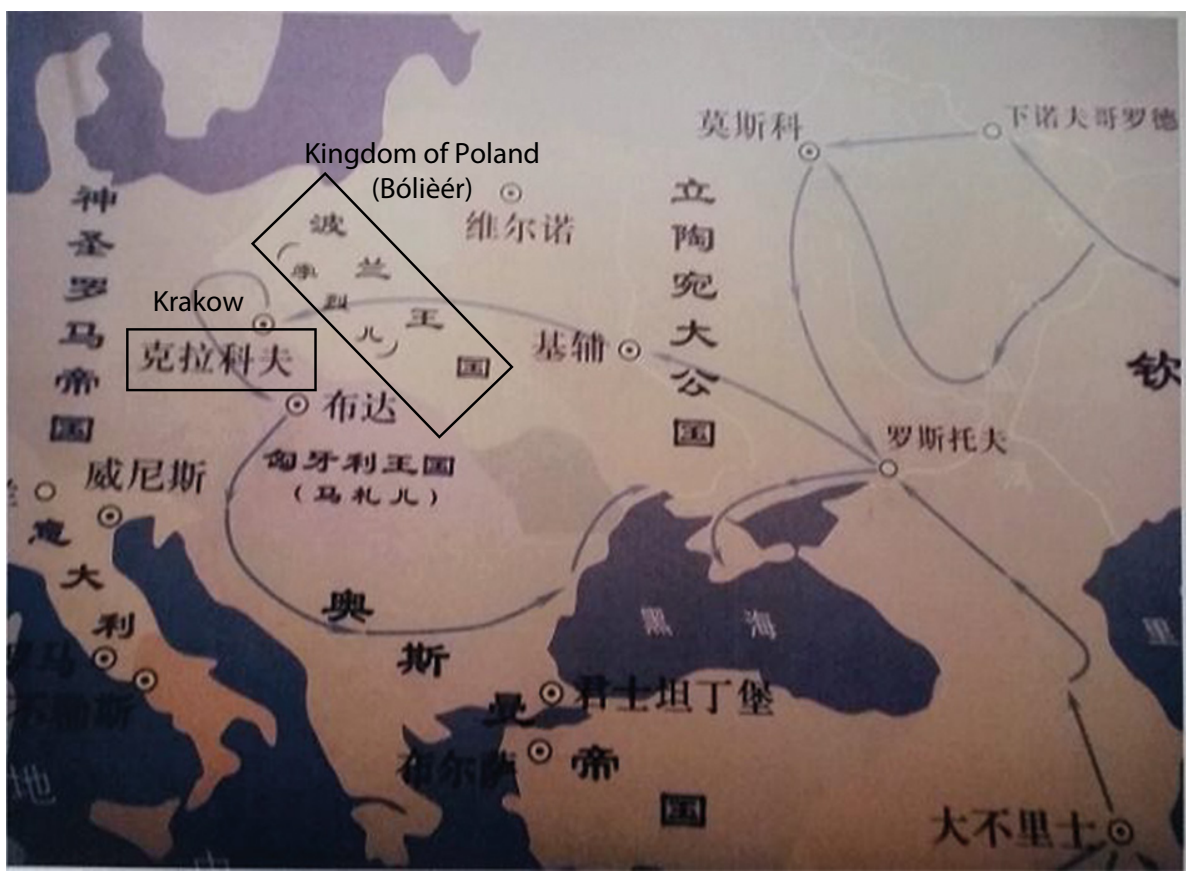

Map 3. The enlarged portion from Map No. 2, depicting the location of Poland during the Yuan Dynasty.

孛烈儿 (pinyin: Bólièér), the name of Poland, and 克拉科夫 (pinyin: Kèlākēfū, English language: Krakow), the capital of Poland, appears on the map.

Source: Capital Museum in Beijing (the photo was taken on July 5, 2017).

In Hukar Il, in the year of the death of Ogedei Khan (1241), in the spring months, they (i.e. Mongolian commanders) set off through Maraktan mountains to Bulars and Bashghords. Orda and Baidar departing from the right wing, reached the land of Ilawut. There was B.r.z. with the army against [them], but they defeated him (Hauziński, 1997, p. 372-373).

The Russian sinologist Emil Bretschneider found an ideogram in Chinese chronicles belonging to the court historiography of the Yuan Dynasty, denoting the one of the furthest Western lands, which he called as Ila-ut. Without knowing about courses of Mongol invasions in 1239-1242, he confused it with Lithuania, which caused many incorrect theories, and met with justified criticism, discarding Lithuania as a terrain of the Mongol invasions (Hauziński, 
1997, p. 373). After analyzing the notes of Rashid al-Din, J. Hauziński states that the Arabian chronicler did not combine the Chinese data concerning Mongolian operations in Central Europe with the short description about Mongol invasion on countries belonging to the Western Christianity.

Due to the fact of confirming the name Ila-ut read by Rashid al-Din Hamadani on the basis of Chinese sources and acquiring the range of the battles with Mongols on the Polish terrain, J. Hauziński established a connection between this name and one of the toponyms occurring in Lower Silesia. According to J. Hauziński, the closest phonetic correspondence can be seen in the name Ilawa (in Polish language: Iława). The village is located on the old track leading to Meissen, about $60 \mathrm{~km}$ to the northwest of Legnica (Hauziński, 1997, p. 373).

In the second cycle of the monumental compilation of Rashid-ad-Din, the history of the western world, based largely on the work of Marcin of Opava (Hauziński, 1997, p. 373), contains a brief, or even concise record:

The Mongol army went from Steppe of the Kipchaks to Magyaristan and Bulunijja, killed a lot of people and plundered (those countries). There were so much famine erupted in those lands that people ate their own children. In those lands the starvation, which broke out, was so big, that people ate own children's meat. May Almighty God have mercy on them and may the rain fall down in the form of the flour, thus they can bake the bread and eat (Hauziński, 1997, p. 376).

Rashid al-Din, mentioning the Central European countries, Hungary and Poland, attacked by the Mongols, uses terms derived from classical geographical and historical literature. Despite the terms describing the nations of Central Europe derived from Arab authors, i.e. Majaristan as the land of Magyar (Hungarian), and Bulunijas (from the Latin name Polonia) for Poland, they did not give rise to doubts.

Poland is mentioned under the name Bolar transferred from Volga Bulgaria, which originates from the order of the names of the people covered by the expeditions in 1236-1240:

And (Ögedei) dispatched many sons of Batu, Güyük, Möngke, and the other princes as an aid for Sübetei who once set out against the peoples of Kanglin, 
Kib’czant, Bajigit, Orusut, Asut, Sesüt, Manjar, Kèszimir, Serkesüt, Bolar, Kerel (and reached) beyond the water-rich Wdil Dżajak river to the cities of Meket, Menkermen, Kejbe and others which were then strongly resisted by Sübetei (Hauziński, 1997, p. 178).

The ethnonym Bolar, presenting in the text written by Rashid al-Din in the spelling form of Bular, was connected by the Russian sinologist Emil Bretschneider with Poland who points out the transfer of this name from the Volga Bulgaria. An important argument in favor of this hypothesis was the appearance of an ideogram, in the official version of Yuan Shi, which he reads as Po-lie-rh, signifying Poles (Hauziński, 1997, p. 377). As a matter of fact, this entry should be read as the Chinese ideogram Bólièér which mentioned above means Poland or Poles.

What is surprising is that the term 'Polonia', the latin name of Poland, was applied in many examples of literature of the Qing Dynasty (1636-1912). 皇清職貢圖 Huang Qing Zhigong Tu [Collection of Portraits of Subordinate Peoples of the Qing Dynasty], compiled by the scholar Fu Heng et al. during the period of the Emperor Qianlong (1711-1799), is a historical record of overseas countries and various nationalities. It is considered as an $18^{\text {th }}$-century ethnological study of Chinese tributary states, including Western nations that traded with the Qing Empire (Lorraine, Fernando, 2010, p. 422). The study contains numerous factual errors, such as reporting that France is a Buddhist state before becoming Catholic, and that England and Sweden are vassals of Holland, etc. (Smith, 2013, p. 76). In this book, 波羅泥亞（pinyin: Bōluóníyà) which means Poland is introduced briefly, with the pictures of the inhabitants (see Image No. 4 and No. 5), as follows:

The state of Bolonia is located in the eastern part of Germany. People who lived there are very similar to Mongols, with moustache and no beard on their cheeks. Their hair was cut, a pinch of which on the top of the head was only remained and braided hanging on the back of the head. Bolonia was such cold that all the inhabitants wrapped in the furs of fox, marten, raccoon or rat, particularly the ankles. They like to catch bears and then keep them for fun. Women are specialized in housework which are well organized both at 
home and outside. Bolonia is rich in honey, wood, amber, cow, sheep etc. (Fu et al., 2008, p. 37).

The Chinese entry 波羅泥亞 was interpreted phonetically from Bolonia which was derived from the latin word Polonia. As we all known that the letters $\mathrm{p}$ and $\mathrm{b}$ with the similar pronunciation usually are confused as well as the sound of two words, Poland and its Chinese transcription 波兰 (pinyin: Bolan), we produced today.

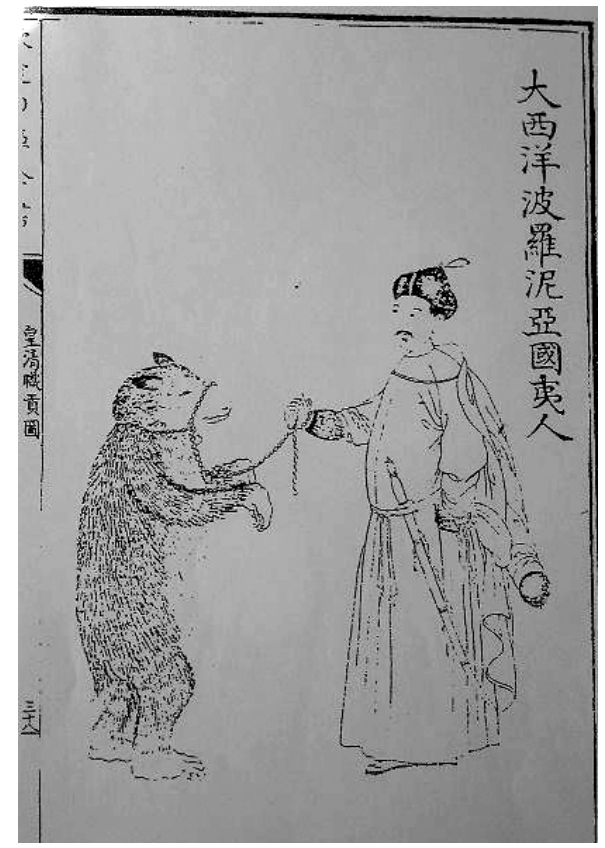

Image 4. Barbarian man of Bolonia in the Great Western Ocean

Sources: Fu et al., 2008, p. 39.

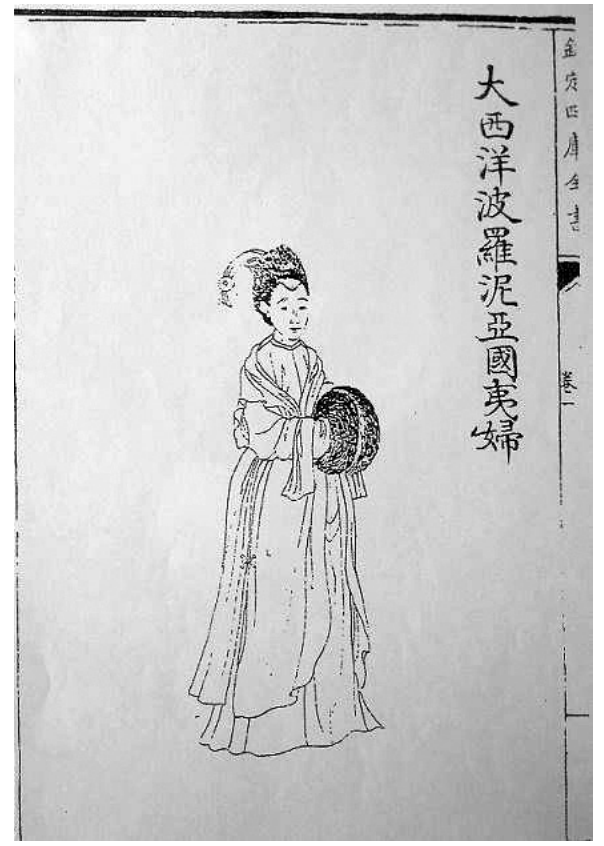

Image 5. Barbarian woman of Bolonia in the Great Western Ocean Sources: Fu et al., 2008, p. 38

Furthermore, the painting entitled "Vassal States and Foreign Countries Presenting Tributes to the Emperor" also offers the evidence. It was painted by palace artists on orders of Emperor Qianlong. The rulers of the Qing Dynasty appraised the Western countries with the eyes of the "Celestial Empire", disregarding the changes in Europe. In the painting, the delegates 


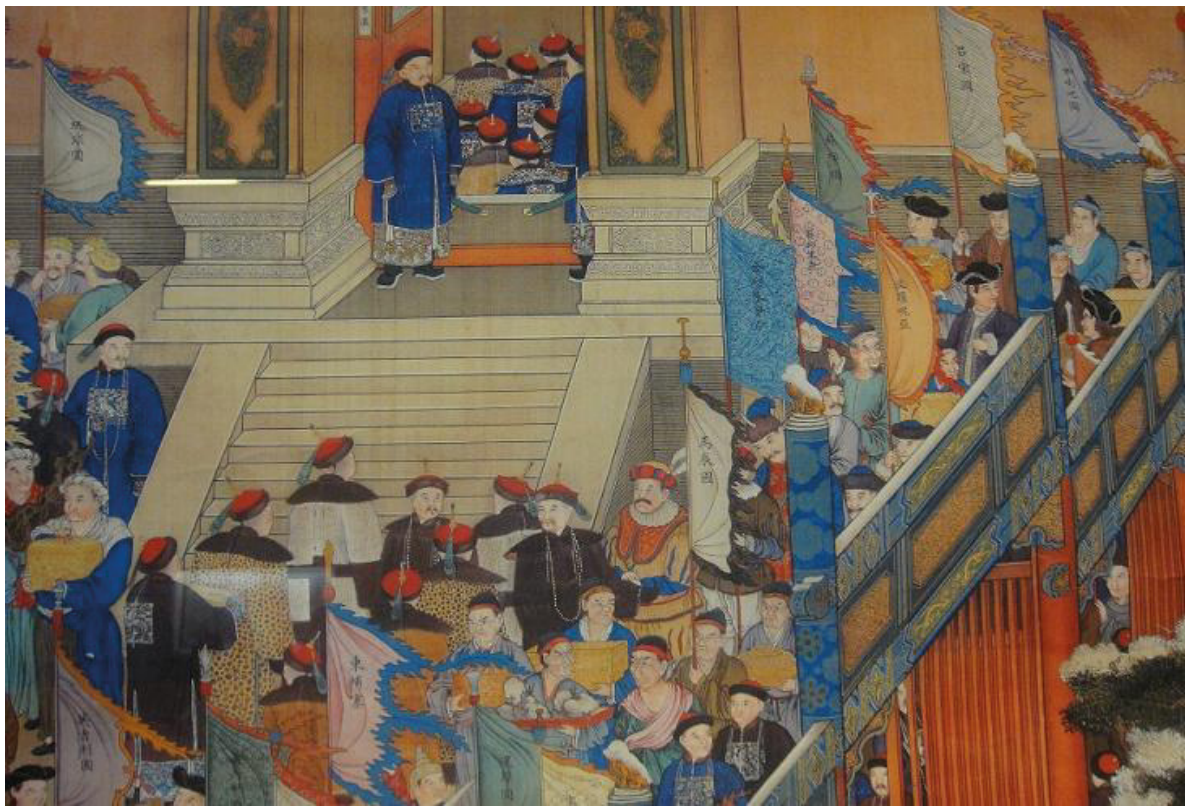

Image 6. Portion of "Vassal States and Foreign Countries Presenting Tributes to the Emperor"

Source: Capital Museum in Beijing (the photo was taken on July 12, 2017).

of each country is holding up the flag marked with the name of their own country. There is a message of Poland - 波羅泥亞 (Bolonia) appearing in the upper right corner of the whole painting (see Image No. 6). It is worth noting that the scene of "all countries", presenting tributes to the Emperor during the period of New Year, is fictional. There is a message of Poland in the upper right corner.

Why has the use of the name of Poland changed so much? When Europe in the thirteenth century experienced the suffering by the Mongol sabers and faced the unknown strategies, tactics and technological developments of the Far East military art, the interest in this region increased enormously (Gumilow, 1973, p. 164-167). It became necessary to have a sufficiently clear view of policies implemented by the rulers who created the largest empire in the world during this period. Europe felt the need to obtain reliable information, and hence the travels to the Far East commenced, and the cognitive 
goals were often supplemented with practical interests (Jochum, 1989, p. 23). The most meaningful information was provided by missionaries among whom some Polish Franciscans and Jesuits reached to the Mongol, even to China, from the $13^{\text {th }}$ to $18^{\text {th }}$ century, such as Benedykt Polak, William of Rubruck, Michal Piotr Boym, Jan Chrzciciel Bakowski, etc. They brought some knowledge about their country including the latin name of Poland to the rulers of China, while recording what they had seen, heard and reflected on during their journeys. Therefore, we can say that the influence of the expeditions to the West by Mongols is exactly visible, which opened up the door to the contact between China and Poland.

\section{Conclusion}

The interaction between China and Poland began in the $13^{\text {th }}$ century. The written records of exchanges between China and Poland were also first found in the $13^{\text {th }}$ century. Large-scale missionary activities had objectively contributed to the collision and conversation among the major civilizations in the world. The recognition of the Chinese people from Poles was also completed in the process. Unfortunately, due to the limited length of the paper, the traces of Polish Franciscans and Jesuits in China have been neither narrated nor discussed in detail. The contacts between China and Poland in history not only realized the cultural exchanges, but also influenced the relations of the two entities. The signing of a number of agreements and the expansion of cooperation in various fields between the two countries are based on the better understanding of the two peoples that has been achieved through the historical interactions.

East Asian Culture and Languages Division

Institute of Russian and Eastern Studies

Faculty of Philology

University of Gdańsk

Polanki 63/202, 80-306 Gdańsk

irisbiwei@gmail.com 


\section{Bibliography}

Bai Shouyi, Zhao Yang (eds). (1982). An Outline History of China. Beijing: Foreign Languages Press.

Bartold, W. (1911). Istorija izuczenija Wostoka w Jewropie i w Rosiji. Peterburg.

Chambers, J. (1979). The Devil's Horsemen: The Mongol Invasion of Europe. New York: Atheneum.

Długosz, J. (1975). Annales seu Cronicae incliti Regni Poloniae, ks. VII-VIII. Warszawa: PWN.

Fu Heng et al. (eds). (2008). Huang Qing Zhigong Tu [Collection of Portraits of Subordinate Peoples of the Qing Dynasty]. Jiangsu: Guangling Shushe.

Gumilow, L. (1973). In the footsteps of civilization of the Great Steppe. Warszawa: Polski Instytut Wydawniczy.

Grousset, R. (2004). Genghis-Khan. Beijing: International Culture Press.

Hauziński, J. (1997). Europa Środkowa i Polska w historiografii orientalnej epoki podbojów mongolskich. W: K. Zielińska-Melkowska (ed), Europa Środkowa $i$ Wschodnia w polityce Piastów. Toruń: Uniwersytet Mikołaja Kopernika.

Hildinger, E. (1997, June). Mongol Invasions: Battle of Liegnitz. Retrieved from: https:// www.historynet.com/mongol-invasions-battle-of-liegnitz.htm.

Jackson, P. (2007). Mongołowie i Zachód. Warszawa: Bellona.

Jochum, A. (1989). Na dworze wielkiego chana, Jan z Monte Corvino (1247-1328), pierwszy Franciszkanin w Chinach. Warszawa: Verbinum.

Juvaini, Ata-Malik (1958). The History of the World-Conqueror Vol. 1. Manchester University Press.

Kałużyński, S. (1970). Tajna historia Mongołów. Anonimowa kronika mongolska $z$ XIII w. Warsaw: Państwowy Instytut Wydawniczy.

Łabęcka-Koecherowa, M. (1987). Koblandy Batyr. Warszawa: Ludowa Spółdzielnia Wydawnicza.

Lorraine, D., Fernando, V. (2010). The Moral Authority of Nature. Chicago: University of Chicago Press.

Luo Zhewen, Zheng Luo (1986). The Great Wall of China in History and Legend. Beijing: Foreign Languages Press.

Maroń, J. (2011). Koczownicy i rycerze - Najazd Mongołów na Polskę w 1241 roku na tle sztuki wojennej Europy XII $i$ XIII wieku. Templum.

Pomorski, J. (1984). W poszukiwaniu modelu historii teoretycznej. Lublin: Zakład Poligraficzny Politechniki Lubelskiej.

Shen Fuwei (2014). Zhong Xi Wenhua Jiaoliu Shi [History of Cultural Exchanges between China and West]. Shanghai: Shanghai People's Publishing House.

Smith, R.J. (2013). Mapping China and Managing the World: Culture, Cartography and Cosmology in Late Imperial Times. Routledge.

Song Lian. Yuan Shi [The History of Yuan]. Retrieved from: http://www.guoxuedashi. com/a/25sxtg/143806l.html.

Sikorski, J. (1975). Zarys historii wojskowej powszechnej do końca XIX w. Warszawa: Wydawnictwo Ministerstwa Obrony Narodowej.

Tatarkiewicz, W. (1978). Parerga. Warszawa: Państwowe Wyd. Naukowe. 
Włodarski, J. (1992). Najazdy Mongołów jako konfrontacja cywilizacji dalekiego wschodu i zachodu. W: J. Śliwiński (ed), Społeczeństwo i kultura do XVI wieku. Olsztyn: Materiały z sesji naukowej.

Włodarski, J. (1997). Historia Dżoczi-syna Czyngis-chana. Gdańsk: Marpress.

Włodarski, J., Zhao Gang (2014). Kontakty Polski z Chinami od XIII do końca XVIII wieku - próba nowego spojrzenia. Gdańskie Studia Azji Wschodniej, 5(2), 14-32. 